\title{
Efficiency of Sweet Potato Farmers in Nigeria: Potentials for Food Security and Poverty Alleviation.
}

\author{
I.M. Ahmad ${ }^{1}$,Makama, S. A. ${ }^{2}$, V.R. Kiresur ${ }^{3}$ and Amina B. S. ${ }^{4}$ \\ ${ }^{1}$ Dept. of Agril.Econs. University of Agricultural Sciences, Dharwad \\ ${ }^{2}$ NAERLS, Ahmadu Bello University, Zaria - Nigeria \\ ${ }^{3}$ Dept. of Agril.Econs. University of Agricultural Sciences, Bijapur \\ ${ }^{4}$ Dept. of Biochemistry, Bayero University Kano, Nigeria.
}

\begin{abstract}
Nigeria is the third largest producer of sweet potatoes in the world in terms of quantity, after China and Uganda. In 2010, Nigeria produced 2.5\% of the world's production of sweet potatoes. However, sweet potatoes are still considered a minor crop in the country. The study examines the economic analysis of Sweet potato production in, Kano State, North-western part of Nigeria. A sample of 120 farmers was randomly analyzed using descriptive statistics, farm budgeting technique, production function and Marginal productivity. The results revealed that majority (43.3\%) of the respondents were within the age of 30 - 42 years, $70.83 \%$ were males, $69.16 \%$ were married, and majority (36.6\%) attended non-formal education and $45 \%$ had farm size of between $0.2-1.0$ hectares. Results further shows that labour cost accounted for $44.1 \%$ of the total cost of production and the gross income per hectare was found to be $\$ 75,553$ with a gross margin of $\$ 45,527$. The result of production function depicts the coefficient of multiple determinations $\left(R^{2}\right)$ to be $91 \%$. It further shows that fertilizer and manure were statistically significant at $1 \%$, and $1 \%$ level of probability respectively. Moreover, the result of resource use efficiency reveals that farmers under utilized resources like fertilizer, manure, Seed and pesticide, except labour. Findings also revealed that, high cost of inputs; poor access to credit, poor price, pest and diseases as well as poor access to markets were among the major constraints faced by the farmers in the study area. Therefore, the study concludes that Sweet Potato production in the study area is profitable. Hence for profit improvement there is need for resource adjustment. Government on the other side should ensure timely supply of agricultural inputs at subsidized rate, provision of storage facilities and market for output in order to achieve food sufficiency and reduce poverty among farmers. The study indicated that higher yield of sweet potato could be achieved through improved sweet potato variety and application of small quantities of fertilizer as sweet potato can grow well with application small quantities of fertilizer such that is widely produced among rural poor.
\end{abstract}

Keywords: Sweet Potato, efficiency, food security, poverty.

\section{Introduction}

Sweet potatoes offer a particularly significant potential for increasing food production and income there by reducing poverty and improving food security level in Nigeria. Sweet potatoes are consumed without much processing in most parts of the tropics.

Sweet potatoes present diverse industrial uses, some of which are potentially highly profitable, such as sweet potato snacks. (Adewumi, et al., 2008)

Sweet potatoes are extremely adaptable to adverse environmental conditions; they can help increase food security in times of drought and famine, particularly in post-conflict areas for displaced persons. (Andrade et al., 2009). Sweet potatoes produce carbohydrates much faster and require less labor than other crops. Sweet potatoes are used to restore access to food for resetting populations and alleviate future agro-climatic or political shocks. The challenge with using sweet potatoes in emergency response situations is the crop's low multiplication rate. Vine material needs to be ready to go and mechanisms in place to distribute vine materials to needy farmers. (Andrade et al.,2009).

A number of initiatives in Nigeria encourage consumption of orange-fleshed sweet potatoes, which contain beta-carotene and help fight vitamin A deficiency, which can result in blindness for pregnant women and children and even death for 250,000-500,000 children per year. (Anyaegbunam, et al., 2011) In Nigeria, estimates suggest $29.5 \%$ of all children under the age of five are vitamin-A deficient. (Burri, 2011)

A comparison of sweet potatoes to maize, potatoes and cassava shows that sweet potatoes yield more calories per hectare than maize or potatoes and nearly as much as cassava. Sweet potatoes also yield larger amounts of protein in kilograms per hectare than cassava.

Nigeria is the third largest producer of sweet potatoes in the world in terms of quantity, after China and Uganda. In 2010, Nigeria produced $2.5 \%$ of the world's production of sweet potatoes. However, sweet potatoes are still considered a minor crop in the country. In 2010, sweet potatoes had the tenth highest production level of 
any single food crop in Nigeria (after cassava, yam, oil palm fruit, maize, sorghum, millet, paddy rice, and plantains). In 2010, the gross agricultural production value for sweet potatoes was \$954 million USD and accounted for $1.73 \%$ of total agricultural production value for all crops.

Although a sweet potato is a crop that is consumed in all parts of the country, its level of production still remains low. The world sweet potatoes sector is however undergoing major changes. Worldwide, sweet potato's production and consumption is huge. All over the world people eat and use this super food. The crop ranks among the five most important food crops in over 50 developing countries (Dogondaji, 2005).

This paper reports the findings of the profitability studies of Sweet Potato Production in Kano State, Northern part of Nigeria. Specifically the study aimed at: describing the socio-economic characteristics of Sweet Potato farmers and determining it is profitability as a means of attaining sustainable poverty reduction and means for achieving food security in the country.

The objective of this study is therefore to determine the efficiency of rice farmers in Nigeria and the potentials for expansion of output. The specific objectives are to:

1. to analyse the socio-economic characteristics of Sweet Potato farmers in Nigeria;

2. to analyse the profitability of sweet potato cultivation and;

3. toestimatethe technical efficiency of Sweet Potato farmers in Nigeria.

\section{Methodology}

\section{Data And Methodology}

For this study, farm level data were collected on 120 Sweet potato farmers in Kano State, Nigeria. Kano State is one of the 36 States of Nigeria located in the North-Western part of Nigeria.

\section{Sampling Technique}

Three-phase multistage sampling programme for the choice of Local Government Areas, communities and households were carried out.

\section{Data Collection}

Primary data were generated through the use of structured questionnaires that were distributed and administered to Sweet potato farmers. Secondary data and information were collected from published materials like journals, proceedings, textbooks etc. World Bank sources and Food and Agriculture Organization (FAO) etc constituted other sources of secondary data as well.

\section{Method of Data Analysis}

Descriptive statistics such as graphical analysis, percentages, range,etc were used for the analysis of specific objectives (i). Inferential statistics such as Cobb-Douglas stochastic frontier production function, multiple regression analysis etc were used for the analysis of specific objectives ii \& iii.

\section{Model specification}

The stochastic frontier production function for Sweet Potato production adopted in this study as specified by the Cobb-Douglas functional form (Seyoum et.al., 1998) is defined thus:

$\log Y i=b+b_{1} \log x_{1}+b_{2} \log x_{2}+b_{3} \log x_{3}+b_{4} \log x_{4}+b_{5} \log x_{5}+e$.

Where $\mathrm{Yi}=$ output ofi th farmer $(\mathrm{kg})$

$\mathrm{X} 1=$ is farm size (ha)

$\mathrm{X} 2$ = is labour in man-days

$\mathrm{X} 3=$ fertilizer in $\mathrm{kg}$

$\mathrm{X} 4=$ Agro chemical in litre

$\mathrm{X} 5$ = quantity of seed planted in $\mathrm{kg}$.

Sweet potato output is expected to be influenced positively by farm size, labour, fertilizer used, agrochemical and quantity of seed planted.

The functional form for the stochastic frontier is defined by equation (1). The function is a modified version of a Cobb-Douglas model. It permits different levels of productivity associated with different proportions of farm size, labour etc. 
III. Results And Discussion

Table 1: Percentage distribution of some demographic characteristics of Nigerian Sweet Potato farmers.

\begin{tabular}{lll}
\hline Factors & Frequency & Percentage \\
\hline a. age & 40 & 33.33 \\
$17-29$ & 52 & 43.33 \\
$30-42$ & 19 & 15.83 \\
$43-55$ & 09 & 7.5 \\
$>56$ & 120 & 100 \\
Total & & \\
& & \\
b. Sex & 85 & 70.83 \\
Male & 35 & 29.16 \\
Female & 120 & 100 \\
Total & & \\
& & \\
c. marital Status & 83 & 69.16 \\
Married & 37 & 31.14 \\
Single & 120 & 100 \\
Total & &
\end{tabular}

Source: Field Survey, 2011.

Table 2: Percentage distribution of some selected Socio-economic characteristics of Nigerian Sweet Potato farmers.

\begin{tabular}{lcc}
\hline Variables & Frequency & Percentage \\
\hline a..Level of education & & \\
Non formal & 47 & 36.67 \\
Adult & 20 & 16.67 \\
Primary & 35 & 30.00 \\
Secondary & 12 & 10.00 \\
Post-Secondary & 08 & 6.67 \\
$\quad$ Total & 120 & 100 \\
b. House hold size & & \\
$1-10$ & 86 & 71.66 \\
$11-20$ & 30 & 25.00 \\
$21-30$ & 04 & 3.34 \\
Total & 120 & 100 \\
& & \\
c. farming experience (years) & & 85.83 \\
$1-15$ & 103 & 10.00 \\
$16-30$ & 12 & 0.83 \\
$31-45$ & 01 & 4.16 \\
$\geq 46$ & 05 & 100 \\
$\quad$ Total & 120 & \\
d. Farm size (ha) & & 45.83 \\
$0.2-0.7$ & 55 & 19.16 \\
$0.8-1.3$ & 23 & 7.50 \\
$1.4-1.9$ & 09 & 20.83 \\
$2.0-2.5$ & 25 & 6.66 \\
$\geq 2.6$ & 08 & 100 \\
$\quad$ Total & 120 & \\
\hline
\end{tabular}

\section{Source: Field Survey, 2012.}

Many of the respondents $43.33 \%$ fall between the age of 30 and 42 years. In all, more than $59.16 \%$ of the respondents were between the age of 30 and 55 years. This result suggests that most of the farmers are young people who are still strong and full of energy to make meaningful impact in agricultural production. The average age of the sample respondents was 39 years. This was close to the research finding of Okoruwa and Ogundele (2003) which put the average of Nigerian Sweet Potato farmers at 42 years. 
Sweet potato producers in the study area are dominated by the male which accounts for $71 \%$ of the respondents indicating that men who naturally are the stronger gender carry out most of the activities on the farms. This result suggests that sex increases technical efficiency of Sweet potato farmers in the study area.

The study revealed that the largest proportion of the respondents (69.2\%) was married. About $36.6 \%$ of the respondents had no formal education, $30 \%$ and $10 \%$ attended primary and secondary schools respectively. About $7 \%$ and $17 \%$ attended post-secondary school and adult education respectively. In all, about $63.4 \%$ of the respondents are literate farmers. This result is in agreement with the finding of Akpokodje et.al. (2003) that majority of Sweet potato farmers in Nigeria could read and write.

Majority of the respondent (71.6\%) had between 1-10 household size, $25 \%$ had between 11-20 household size, while $3.3 \%$ had $21-30$ household size. This result suggests that there would be adequate supply of family labour in the study area.

Most of the respondents $(85.8 \%$ ) have been growing Sweet potato between 1 to 15 years, $10 \%$ have been growing Sweet potato between 16 and 30 years, $0.83 \%$ have been growing Sweet potato between 31 and 45 years while $4.16 \%$ had been growing Sweet potato for more than $46 y$ years. The average farming experiences of Sweet potato farmers in the study area is 16.1 years.

About $45.8 \%$ of the respondents have farm size of between $0.2-0.7$ hectares under Sweet potato cultivation, 19.2\% had between 0.8 and 1.3 hectares, $7.5 \%$ had between 2 and 2.5 hectares and $6.6 \%$ had 2.6 hectares or more. The mean farm size per farm family was 1.52 hectares.

\subsubsection{Estimate of Costs and Returns Analysis:}

This section shows the quantity of inputs used, cost and the total revenue realized from the sale of Sweet potato. Total variable cost to cultivate a hectare of sweet potato in the study area is N30,026. An average of N75, 553/ha is accrues to a farmer as a revenue, and N45, 527.00 is left as gross margin. The average net farm income was N44, 222.1. The positive and large farm income indicated return is higher than the cost as such; Sweet Potato production in the study area is profitable. This coincides with the findings of Tewe et al, (2003) that Sweet potato production in Oyo state was found to be very profitable. It also agrees with Ogbonna et al,(2004), that despite it is high production cost, farmers are encourage to go into Sweet Potato production as it appear to be profitable.

Also in the table, the average rate of return on investment was N2.51k. This implies that for every N1.00k invested in producing one kilogram of Sweet Potato,N1.51k was realized. Similarly, Adebayo et al, (2006), found that Sweet Potato is more profitable compared to Coco yam. Abu et al, (2003)found that the relative ease and lower cost of sweet potato cultivation as compared to cereals and other root crops makes it increasingly popular among farmers. This is also attributable to the rising cost of inputs such as fertiliser, which is not usually used in sweet potato production.

Table 3: Cost and Returns structure of respondents

\begin{tabular}{lcc}
\hline Cost items and Revenue & Cost(N/Ha) & Percentage \\
\hline Labour Costs & $13,823.3$ & 44.10 \\
Fertilizer Cost & $8,126.3$ & 25.93 \\
Seed Cost & 5,063 & 16.15 \\
Transportation Cost & $1,110.9$ & 3.5 \\
Manure Cost & 1,250 & 3.98 \\
Chemical Cost & 652.4 & 2.08 \\
Total Variable Cost & $\mathbf{3 0 , 0 2 6}$ & \\
Fixed Cost & & \\
Farm tools(Depreciation) & 543.5 & 2.7 \\
Cost of renting land & 761.4 & \\
& & \\
Total Fixed Cost & $\mathbf{1 3 0 4 . 9}$ & \\
Total Cost & $\mathbf{3 1 , 3 3 0 . 9}$ & \\
Returns & & \\
Gross income/ha & 75,553 & \\
Gross Margin & 45,527 & \\
Net farm income & $44,222.1$ & \\
Returns on Naira Invested & 2.51 & \\
Operation ratio & 0.41 & \\
Gross ratio & 0.39 & \\
\hline
\end{tabular}

Source: Field survey data, 2012 


\subsubsection{Estimated Sweet Potato Production Function:}

To determine the marginal productivities for resource use in Sweet Potato enterprise and the efficiency of their use, the production function was utilized. The regression results indicate that about 91 percent $\left(\mathrm{R}^{2}\right)$ of the variation in the output of sweet Potato is jointly explained by the explanatory variables included in the model. The remaining 9 percent were not explained by the explanatory variables which could be attributed to the error or random disturbance in the model. The F-ratio of 97.82 was significant at 1 percent level, implying that the explanatory variables included in the model have strong explanatory power. The F-ratio is a measure of joint significance of all the explanatory variables. It could be seen from the table that the intercept was positive, implying about $7.7653 \mathrm{Kg}$ could be obtained at zero commitment of inputs. The regression coefficient with respect to the explanatory variables were found to be positive in Land $\left(\mathrm{X}_{1}\right)$, fertilizer $\left(\mathrm{X}_{2}\right)$ Seed $\left(\mathrm{X}_{3}\right)$, labour $\left(\mathrm{X}_{4}\right)$ and pesticide (X5). One unit increase in any of the positively signed inputs would increase in sweet potato output by proportion corresponding to the regression co-efficient of the variable in question, all other inputs held constant. It should be noted however, that seed was not statistically significant.

In various studies conducted by Yusuf, et al. (2010), Oluwatayo, et al. (2008), farm size, seed, fertilizer, capital input were found to have positive co-efficient.

Table 4: Estimate of Sweet Potato Production Function

\begin{tabular}{lccc}
\hline Variable & Coefficient & Standard error & t-value \\
\hline Constant & 7.76530102 & 0.34227021 & 19.725 \\
Land & 0.33911541 & 0.08017066 & 4.230 \\
Fertilizer & 0.24000594 & 0.05308450 & 4.521 \\
Seed & 0.07518595 & 0.06134259 & 1.226 \\
Labour & 0.35245082 & 0.09440535 & 3.733 \\
Pesticide & 0.20382760 & 0.12090738 & 5.321 \\
RETURN TO SCALE 1.21 & & \\
\hline
\end{tabular}

Source: Field Survey, 2012.

\section{Estimate for resource Use Efficiency in Sweet Potato input}

Efficiency is the use of available resources as a major pivot for a profitable farm enterprise (Okorji and Obiechina, 1985 in Stephen et al, 2004). Table 4 shows the computed resource use efficiency in Sweet Potato production in the study area. The table depicts that the ratios of Manure, Seed, Pesticide and Fertilizer were greater than one $(r>1)$ which implies inefficient utilization as the sampled farmers under-utilized these inputs. This may be due to their high price and scarcity especially in the case of fertilizer and seed as politics determine it is distribution.Theunder utilization of Seed and Fertilizer was also reported by Yusuf et al. 2010. The efficiency ratio for labour was less than one $(r<1)$ showing that the sampled farmers over-utilized labour on their farms. The reason could be due to low wage rate for labour and excessive use of family labour which is readily available, cheap or even free. This agrees with the findings of Oluwatayoet al. (2008), who reported over utilization of labour in their studies.

This shows that Sweet Potato output is likely to increase and hence revenue if more of such inputs (Manure, Seed, Pesticide, Fertilizer, labour) had been utilized efficiently.

Table 5: Estimates of Resource Use Efficiency in Sweet Potato inputs

\begin{tabular}{lccccc}
\hline Variable & MPP & MVP & MFC & R-ratio & Decision \\
\hline Manure $\left(\mathrm{X}_{1}\right)$ & 1.316 & 79.006 & 5.301 & 14.9 & Under Utilized \\
Fertilizer $\left(\mathrm{X}_{2}\right)$ & 4.198 & 253.12 & 68.34 & 3.703 & Under Utilized \\
Seed $\left(\mathrm{X}_{3}\right)$ & 0.431 & 25.93 & 6.71 & 3.86 & Under Utilized \\
Labour $\left(\mathrm{X}_{4}\right)$ & 0.064 & 3.85 & 263.5 & 0.014 & Over Utilized \\
Pesticide $\left(\mathrm{X}_{5}\right)$ & 8.178 & 493.21 & 161.21 & 3.05 & Under Utilized \\
\hline
\end{tabular}

Source: Field Survey, 2012.

\section{Conclusion And Recommendation}

All the tuber crops together presently contribute $5.4 \%$ to the food and nutrition to humankind with Potato contributing 2.3\%. The realization of the Nigerian Government Agricultural Policy objective in the Sweet potato sub-sector will continue to be a mirage going by the current state of technology in the industry. The Sweet potato farmer specificunder-utilized factors which include manure, fertilizer, seed and pesticide and improved variety, are other key issues which constraint the setting of the industry on a clear path of growth and development. These elements have therefore beclouded the potentials of the industry for full realization of food security and poverty alleviation. It is therefore recommended that the Government and other relevant agencies should improve Sweet potatofarmers access to improved varieties, modern storage technology, markets and extension services. Adequate financial assistance and credit facilities should also be made available to the Sweet potato farmers to enable them expand the crop output. 


\section{Literature Cited}

[1]. Abu, I. A. (2003). Economics of production and postharvest technology in Food yams: Advances in research. In: Okwor, G.C, Asiedu, R.A,Ekanayake, I.J (eds.). NRCRI Umudike/IITA, Ibadan, Nigeria.Pp.187-214.

[2]. Adebayo, I.U. (2006). Statistical method of detecting differences between treatment means. SNAAP Press(Nig.) Ltd., Enugu, Nigeria Pp 1-14.

[3]. Adewumi, M.O.,\& Adebayo, F.A. (2008). Profitability and technical efficiency of Sweet Potato production in Nigeria.Journal of Rural development, 31(5), 105-120.

[4]. Akpokodje, G., Lancon, F., Erenstein, O. (2001). Nigeria's rice economy; state of art paper presented at the Nigerian Institute for Social and Economic Research (NISER)/West Africa Rice Development Association (WARDA), Nigeria rice Economy stakeholders workshop Ibadan, 8-9 November, 55pp.

[5]. Andrade, M., Baker,et al (2009). Unleashing the potentials ofSweet Potato in Sub-Saharan Africa: Current challenges and way forward. Lima, peru.

[6]. Anyaegbunam, H. N., \&Nto, P.O. (2011).Assessment of the performance of Sweet Potato Marketing System in the South east Agro Ecological zone, Nigeria. American Journal of experimental Agriculture, 1(4), 477-485.

[7]. Dogondaji, S.D, 2006.Economics of Dry Season Onion production and marketing in Sokoto and Kebbistates.AnUnpublishedPh.DDissertation,Department of Agricultural Economic and Extension Usman Dan Fodio University, Sokoto, Nigeria.

[8]. Burri , B.J.(2011). Evaluating sweet potato as an intervention food to prevent vitamin A deficiency.comprehensive reviews in food science and food safety, 10(2), 118-130.doi10

[9]. Ogbonna M.C, Ezedinma CI (2005). Economics of palm oil processing inIhitte/Uboma, Imo State, Nigeria: Agricultural Rebirth for improvedproduction in Nigeria.In Proceedings of the 39th Annual conference ofthe Agricultural society of Nigeria, held at Uniben, Benin city, Nigeria,Oct. 9th -13th 2005. pp. 148-151

[10]. Okoruwa, V. O. and Ogundele, O.O. (2003).Technical efficiency.Differentials in rice Production technologies in Nigeria pp.16.http//www. Csae.ox.Ac.uk/conference/zoo6-E01- RPI/Papers/case/okoruwa.Pdf.

[11]. Oluwatayo, C.E. Igwe, K.C. and Mbanasor, J.A. 2008. Application of stochastic frontier production function to the measurement of technical efficiency in yam production in Nassarawastate.Nigeria Journal of Sustainable tropical Agricultural Research.13 20-25

[12]. Seyoum, E. T., Battese, G. E and Fleming, E. M. (1998). Technical Efficiency and Productivity of Maize producers in Eastern Ethiopia: A study of Farmers within and outside the Sasakawa-Global 2000 project. Agricultural Economics 19:341-348.

[13]. Stephen, A., Ezulike, T.O., Nwauzor, E.C.,Asumugha GN (2004). Rate of Return on improve Sweetpotato Production in the forest zone of Nigeria. Nig. Agric. J. vol. 30: 108-114. Babalola O (2000). Soil Management and conservation in Nigeria. In: Agronomy in Nigeria. MO Akoroda (ed). pp. 216-222.

[14]. Tewe L.S., Okonkwo J.C., Ikeorgu J, Ugwu BO, Ene LSO (2003). EconomicsofSweetpotato production using improved management systems. In: NRCRI, Annual Report, 1989. NRCRI, Umudike, Nigeria.pp. 52-54.

[15]. Yusuf, O.M. and Kalu, B.A. (2010). FarmingSystem Study: Participatory RuralAppraisal of PigeonpeaCroppingSystems in Southern Guinea Savannaof Nigeria.Journal on Environment2(1) 112-121. 